\title{
Relative Prices and Sectoral Productivity
}

\author{
Margarida Duarte \\ University of Toronto \\ Diego Restuccia \\ University of Toronto
}

January 2011

\begin{abstract}
We develop a model of the structural transformation with three sectors: agriculture, industry, and services. In addition to reallocation across sectors over time, the model also features a reallocation of consumption across services that differ in their labor intensity and a distribution sector. We use the model to infer sectoral productivity levels across countries by imposing restrictions from data on sectoral employment and final expenditure relative prices. The model implies that productivity levels in services relative to industry are lower in poor relative to rich countries, even though the final expenditure price of services to goods is higher in rich relative to poor countries. These sectoral labor productivity implications across countries are broadly consistent with the available sectoral data. The results suggest that improving productivity levels in services is critical in the aggregate productivity catch up of poor relative to rich countries.
\end{abstract}

Keywords: structural transformation, relative prices, sectoral productivity JEL Classification: O1, O4. 